\title{
SULEGe
}

International Journal of Environment and Geoinformatics (IJEGEO) is an international, multidisciplinary, peer reviewed, open access journal.

\section{Analysis of the Kura River flooding in Azerbaijan territory in 2010 based on Hydrometeorologicall Observation and Remote Sensing}

\author{
Amil AGHAYEV \& Rza MAHMUDOV
}

\author{
Chief in Editor \\ Prof. Dr. Cem Gazioğlu \\ Co-Editor \\ Prof. Dr. Dursun Zafer Şeker, Prof. Dr. Şinasi Kaya, \\ Prof. Dr. Ayş̧egül Tanık and Assist. Prof. Dr. Volkan Demir
}

Editorial Committee (2019)

Assos. Prof. Dr. Abdullah Aksu (TR), Prof. Dr. Bedri Alpar (TR), Prof. Dr. Lale Balas (TR), Prof. Dr. Levent Bat (TR), Prof. Dr. Paul Bates (UK), Prof. Dr. Bülent Bayram (TR), Prof. Dr. Luis M. Botana (ES), Prof. Dr. Nuray Çağlar (TR), Prof. Dr. Sukanta Dash (IN), Dr. Soofia T. Elias (UK), Prof. Dr. A. Evren Erginal (TR), Assoc. Prof. Dr. Cüneyt Erenoğlu (TR), Dr. Dieter Fritsch (DE), Assos. Prof. Dr. Çiğdem Göksel (TR), Prof.Dr. Lena Halounova (CZ), Prof. Dr. Manik Kalubarme (IN), Dr. Hakan Kaya (TR), Assist. Prof. Dr. Serkan Kükrer (TR), Assoc. Prof. Dr. Maged Marghany (MY), Prof. Dr. Michael Meadows (ZA), Prof. Dr. Nebiye Musaoğlu (TR), Prof. Dr. Erhan Mutlu (TR), Prof. Dr. Masafumi Nakagawa (JP), Prof. Dr. Hasan Özdemir (TR), Prof. Dr. Chryssy Potsiou (GR), Prof. Dr. Erol Sarı (TR), Prof. Dr. Maria Paradiso (IT), Prof. Dr. Petros Patias (GR), Prof. Dr. Elif Sertel (TR), Prof. Dr. Nüket Sivri (TR), Assoc. Prof. Dr. Füsun Balık Şanlı (TR), Prof. Dr. Uğur Şanlı (TR), Assoc. Prof. Dr. Oral Yağcı (US), Prof. Dr. Seyfettin Taş (TR), Assoc. Prof. Dr. Ömer Suat Taşkın (TR), Dr. İnese Varna (LV), Dr. Petra Visser (NL), Prof. Dr. Selma Ünlü (TR), Assoc. Prof. Dr. İ. Noyan Yılmaz (AU), Prof. Dr. Murat Yakar (TR), Assit. Prof. Dr. Sibel Zeki (TR)

Abstracting and Indexing: DOAJ, Index Copernicus, OAJI, Scientific Indexing Services, Journal Factor, Google Scholar, Ulrich's Periodicals Directory, WorldCat, DRJ, ResearchBib, SOBIAD 


\title{
Analysis of the Kura River flooding in Azerbaijan territory in 2010 based on Hydrometeorologicall Observation and Remote Sensing
}

\author{
Amil Aghayev*, Rza Mahmudov \\ ${ }^{1}$ National Aviation Academy, AZ1045, Mardakan av. 30, Baku, AZERBAIJAN \\ * Corresponding author: A. Aghayev \\ E-mail: amil_agayev@mail.ru
}

Received 18 Oct 2019

Accepted 10 June 2019

How to cite: Aghayev \& Mahmudov (2018). Analysis of the Kura River flooding in Azerbaijan territory in 2010 based on Hydrometeorologicall Observation and Remote Sensing,. International Journal of Environment and Geoinformatics (IJEGEO), 6(2): 206-212. DOI: 10.30897/jegeo.514468

\begin{abstract}
Because of ongoing global climate change on Earth, along with other natural disasters floods widespread and frequent occurrence of this process in the Kura River basin in Azerbaijan creates great threat for the local population, agriculture and economy of the country. The core objective of the study was the analysis of the flooding in 2010 based on hydrometeorological and satellite data. Assessment of the hydrometeorological parameters that could cause flooding and tendency in comparison of the water level with perennial norm in the Kura River were conducted. Landsat 5 Thematic Mapper (TM) multispectral satellite images reflecting this event were used. The map of flooded areas was developed by the usage of different tools and modules of ArcGIS 10.2.1.
\end{abstract}

Keywords: Floods, the Kura River, Remote Sensing (RS), Geographical Information Systems (GIS), Image Classification.

\section{Introduction}

Flood management requires a good understanding of complex interaction of the geographical space and related spatial information such as surface and groundwater sources, land vegetation cover, land use, meteorological parameters, hydrological condition and human activities (John, 2002; Ertek et al., 2003). Combination of the hydraulic series data within a spatial interface, such as a Geographical Information System (GIS) and Remote Sensing (RS), are the key to graphical visualizations on the hydraulic modelling and effective spatial support for flood risk analysis (Gazioğlu et al., 2014). The increasing availability of very high performance GIS software packages such as ArcGIS opens new opportunities for engineers to perform flood inundation analysis in conjunction with hydraulic models with interactive visualization within immerse decision support environments (Sinnakaudan, et al., 2003; Ghani, et al., 1999; ESRI, 1992; ESRI, 1996; ESRI, 2001; Farhan et al., 2018; Büyüksalih \& Gazioğlu, 2019; Rashidin et al., 2019; Badolava, et al., 2019). In this point of view, study of the 2010 flooding in May in the Kura within Azerbaijan territory through hydrometeorological, GIS and Remote Sensing data is an important issue in the paper.

\section{Study Area}

The water basin of the downstream of the Kura River was selected as the study area (Fig. 1). The territories were object to the impacts of the flood waters in some extent. The last flooding occurred in 2010. The main reasons for the flooding were consistent heavy rains at the same time in Turkey and Georgia, as well as in the territory of Azerbaijan and agricultural activities of people (Abbasov \&Mahmudov, 2009; Махмудов, 2001; Aslanov, 2013). During the flooding increased extreme water level broke protective dikes around the river and caused inundation of some territories mainly in Sabirabad, Saatli, Imishli, Zardab and Shirvan cities (Fig. 2).

Rising of the water level in the riverbed caused not only destruction of dams, but also resulted with the rising of groundwater in the area with little altitude difference to the riverbed, typically from one to several meters (Fig. 3 ). Due to this low difference the territories are constantly under threat. Fluctuation between 0,5-1 meters is sufficient for rising of groundwater level and inundation of residential settlements located close to the river bed.

Usually, Salyan and Neftchala districts were mostly affected regions by floodwaters, but during 2010 flood, there were less inundations there than in other regions (Imishli, Saatli, Sabirabad). Just with the rising of groundwater, the areas close to the riverbed with little altitude difference were subject to the impact of subsoil waters.

Besides from natural flooding in 2010, some areas were inundated intentionally. Therefore, on the 31st May 2010, a new tributary near to the Bahramtapa hydro junction was opened by The Ministry of Emergency Situations of Azerbaijan Republic to overcome the consequences of the flood, clean flooded areas from floodwaters, and to reduce water level (Fig. 4). The stream of the river in near territory to the existing 
Bahramtapa hydrojunction locating on the Aras River and within the administrative boundary of Imishli region was directed to the Mughan plain and thus resulted with the inundation of the most part of the plain.

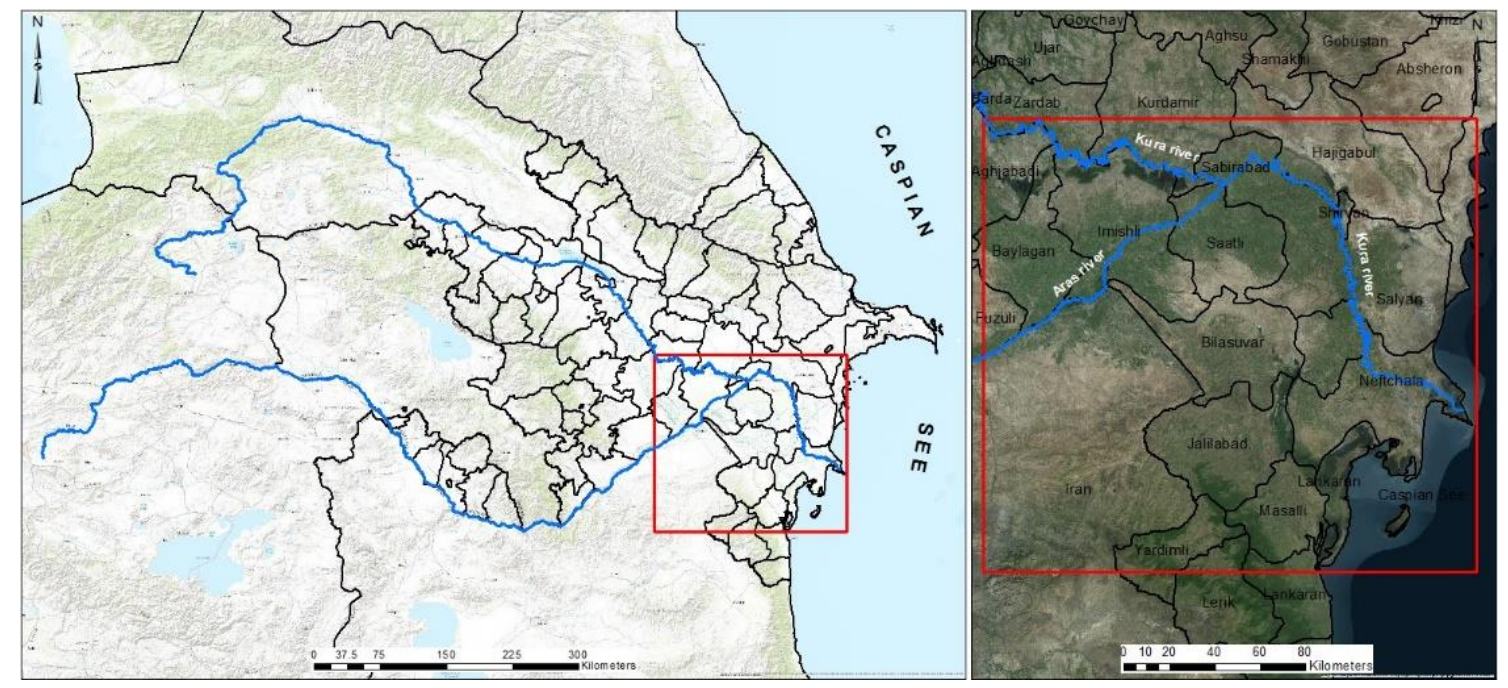

Figure 1. The study area.

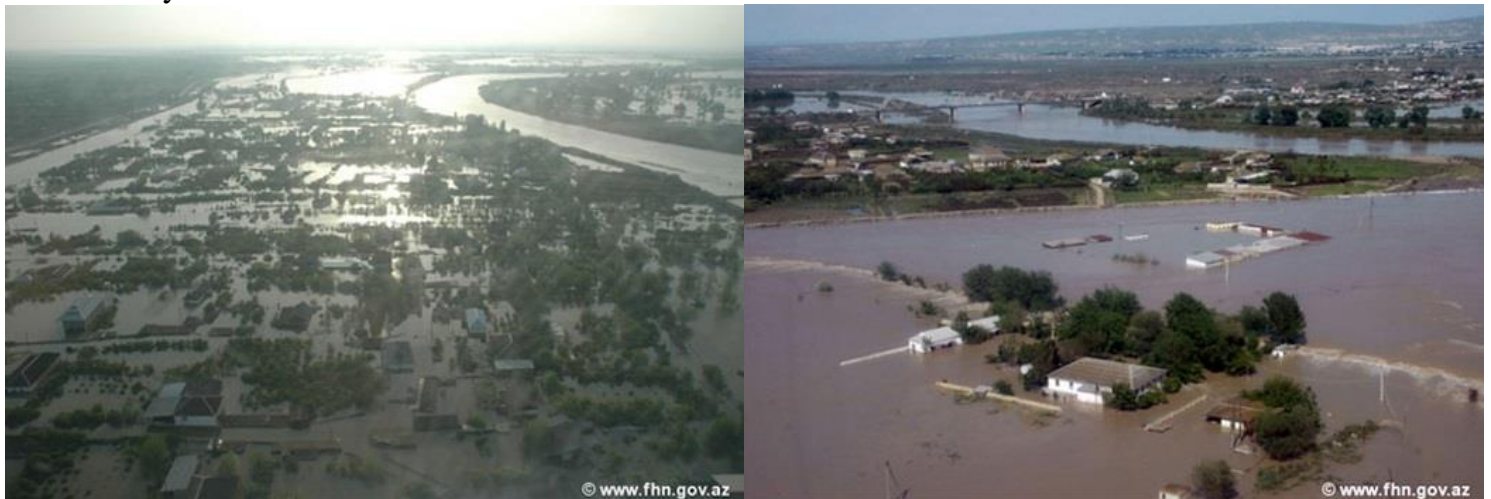

Figure 2. Photos of 2010 flooding (URL 2).

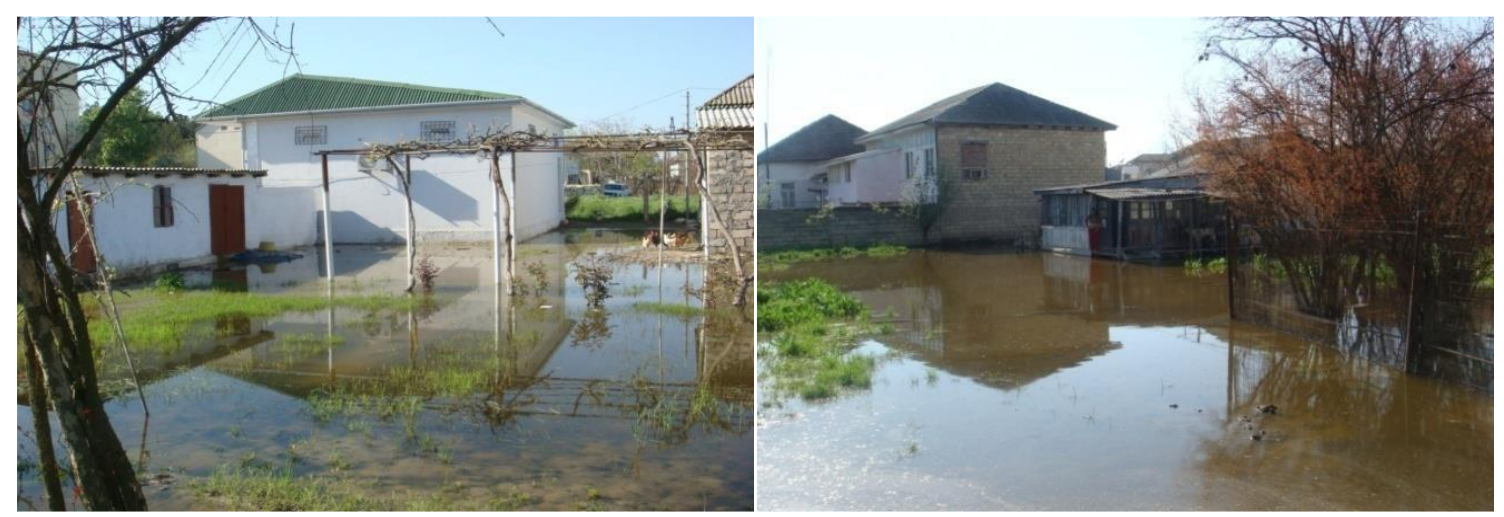

Figure 3. Inundated yards by subsoil waters (spring, 2010) (Есо-миграция, 2013).

During the 2010 flood, a map had been developed based on the data collected from the field surveys during the flood and archival materials by the specialists of the former State Committee of Land and Cartography (SCLC) of Azerbaijan Republic. According to the map 70,000 hectares were inundated:

* Sabirabad region - 43726 ha

* Imishli region - 14770 ha

* Hajigabul region - 2470 ha

* Bilasuvar region - 120 ha

* Saatli region - 8926 ha
The map that was prepared by SCLC was compiled with the use of topographic maps in 1:100000 scale and according to the data of July 7, 2010. Generally, it was difficult to delineate precisely the extent of flooded areas during flood. At that time it was almost impossible to transfer field survey of flooded areas into map accurately. Because flooding covered a larger area in a short period. The only and most simple solution to this problem are remote sensing techniques. The only and most simple solution to the problem is remote sensing techniques. 


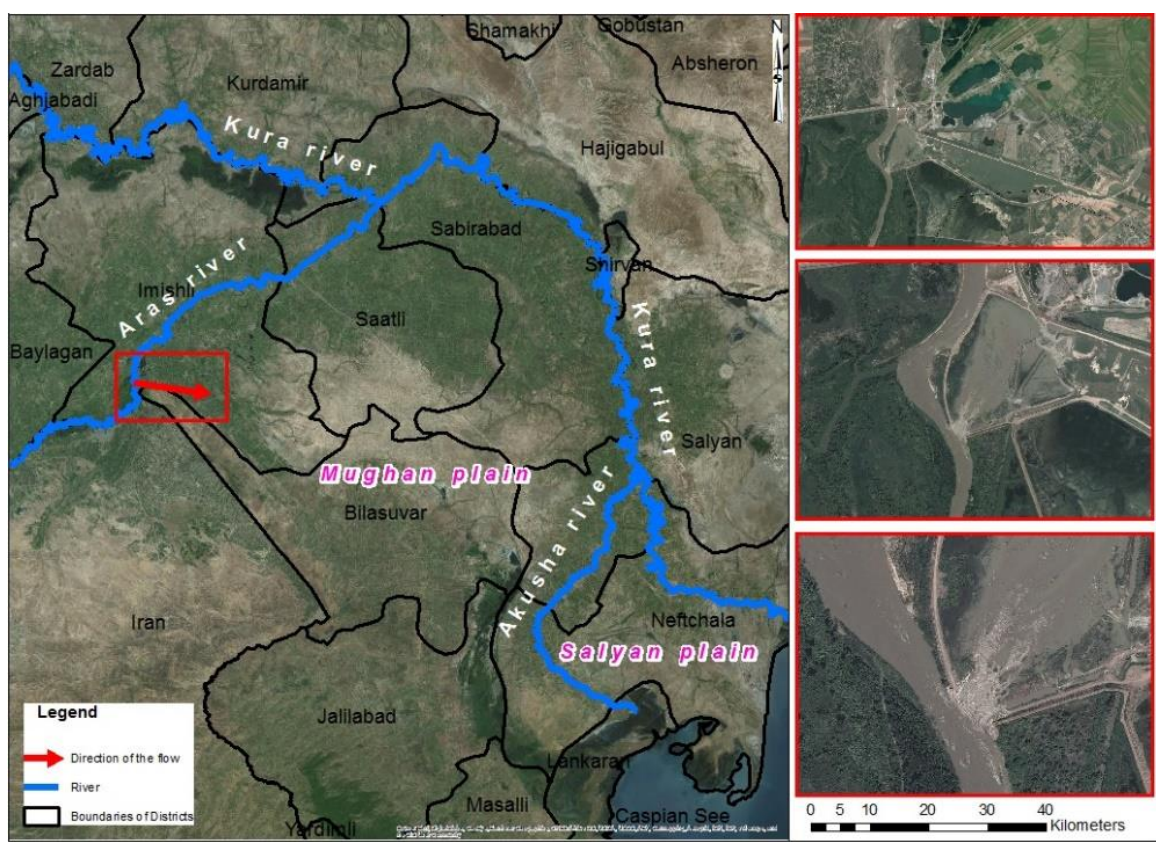

Figure 4. Cartographic presentation of the branch that seperated from the Aras river after 2010 flooding event

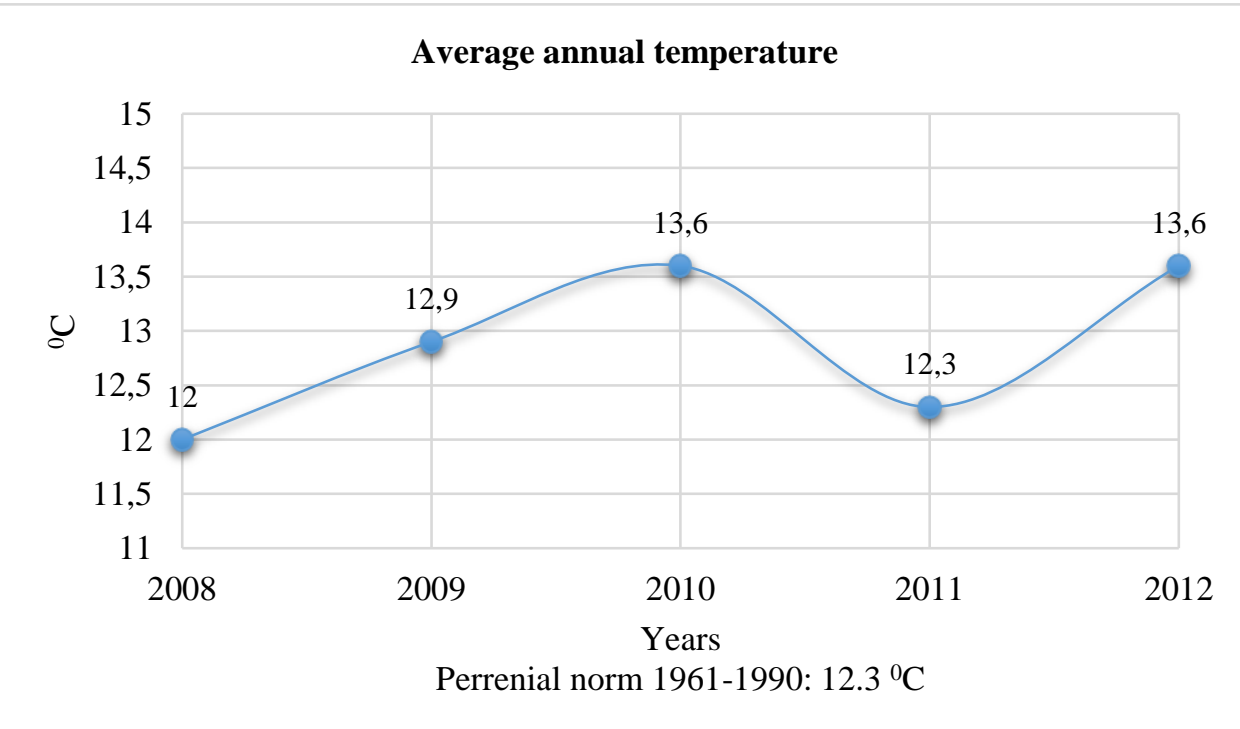

Figure 5. Average annual temperature during 2008-2012 in Azerbaijan.

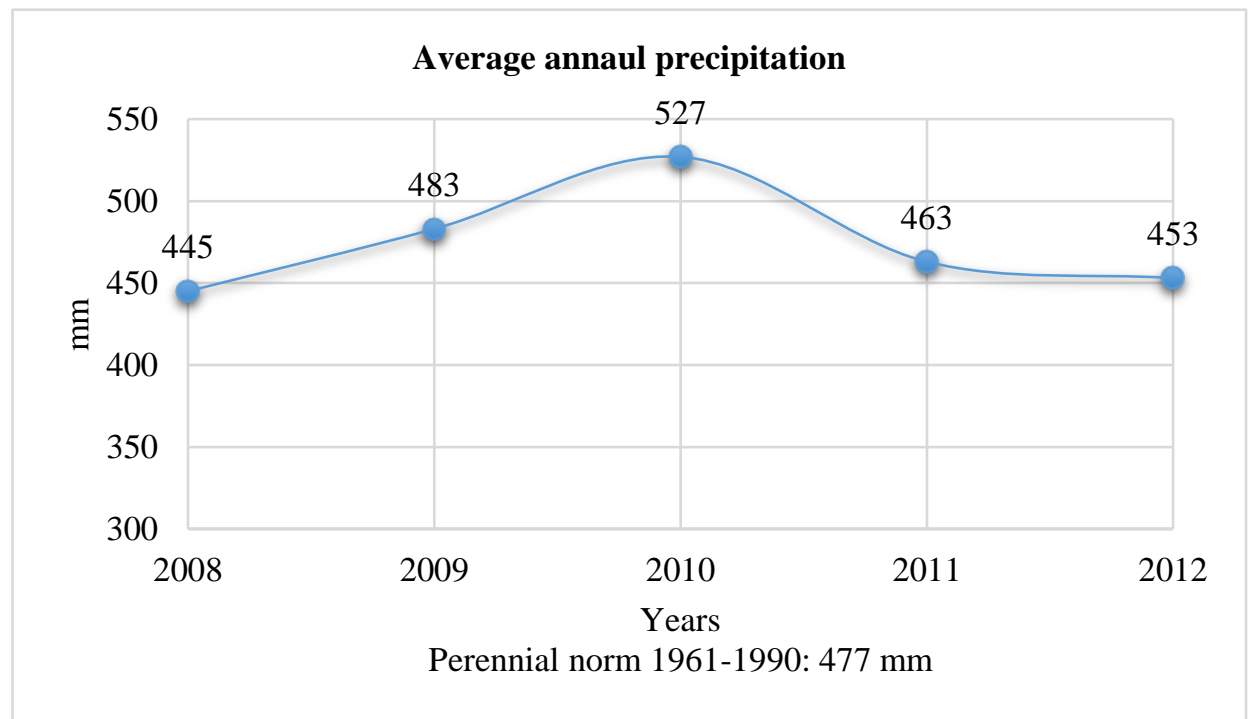

Figure 6. Average annual precipitation during 2008-2012 in Azerbaijan. 


\section{Material and Methods}

The data obtained from The National Hydrometeorology Department of the Ministry of Ecology and Natural Resources of Azerbaijan Republic obviously showed that along with anthropogenic factors, mainly natural factors played a key role in the occurrence of the flood (Mahmudov, 2014; Махмудов, 2016; Mahmudov, 2015). So according to the data the norm of average annual temperature in the country was $12,30 \mathrm{C}$ in 1961 1990, but this figure was $13,60 \mathrm{C}$ in 2010 (Fig. 5). Thus high temperature intensified melting of snow and glaciers in mountainous areas, and in a result it created flooding of rivers.

Furthermore, along with an increase in temperature in 2010, precipitation differed considerably from previous years. Although perennial norm of the precipitation was
$477 \mathrm{~mm}$ in 1961-1990, but this figure was $527 \mathrm{~mm}$ in 2010 (Fig. 6).

The 2010 flooding covered mainly May and June. The following graph shows that monthly perennial norm in 1961-1990 was high in April, May and June absolutely (Fig. 7).

Being higher than the norm of the levels of temperature and precipitation led to sharply rise of the river flow. As a result of continuous rainfall in the neighbouring countries of the Kura River peaked the runoff of the river, critical situation was arose by the drastically level of the water. In considered case, following graph illustrates the shifting level of the water in the Kura River in a particular period. So, from 2008 to 2012, the maximum level of the Kura river reached to $592 \mathrm{~cm}$ in Zardab gauge station in 2010 (Fig. 8).

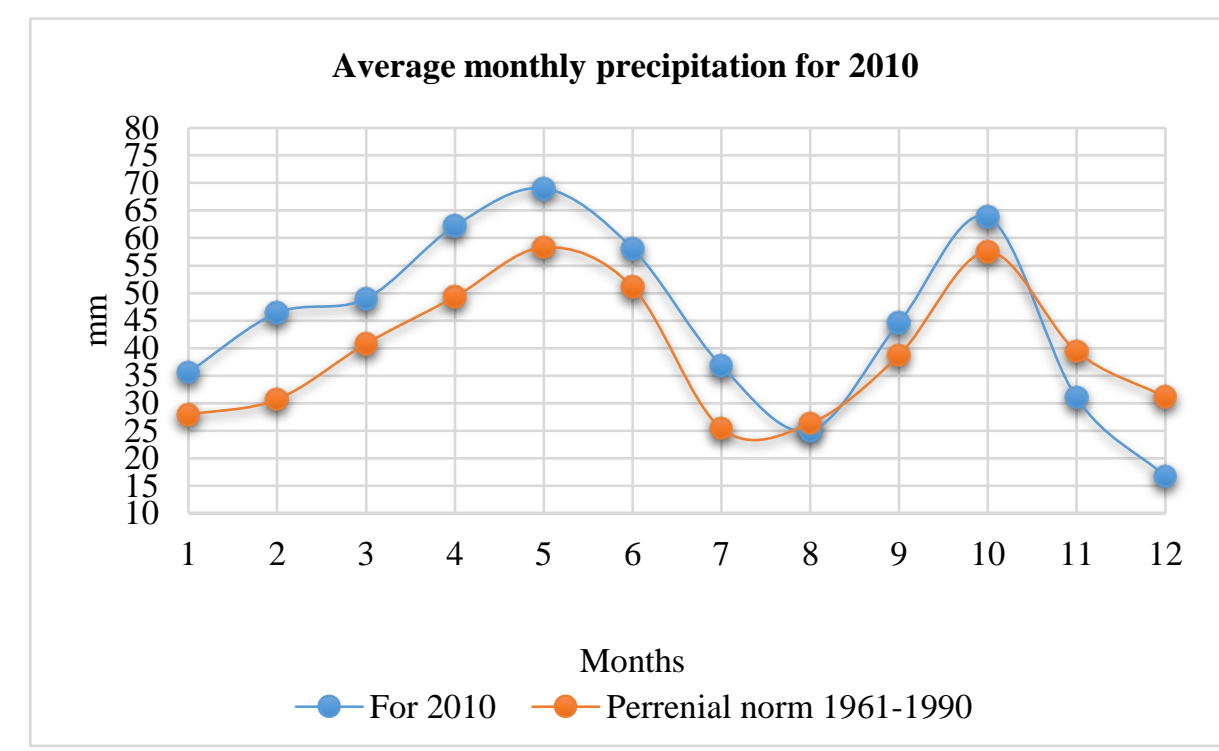

Figure 7. Average annual temperature for 2010 in Azerbaijan.

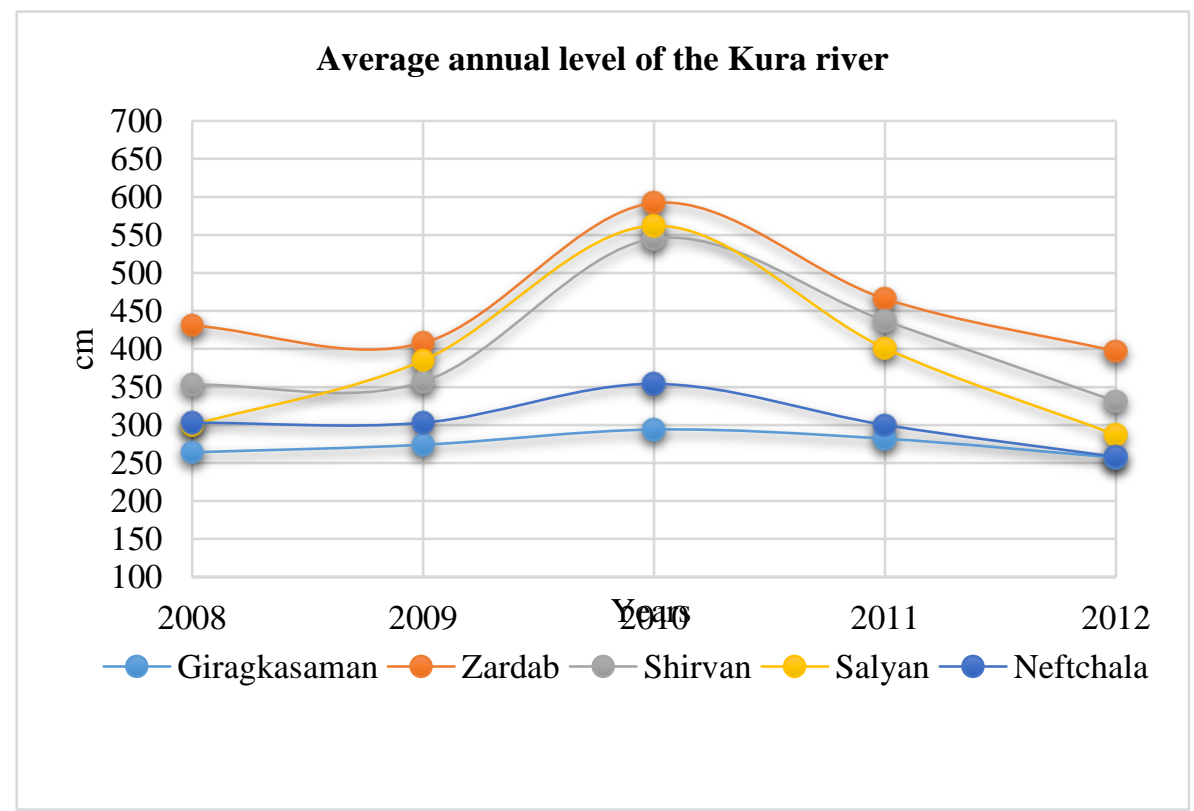

Figure 8. Variation tendency of the average annual level of the Kura River over different station during 2008-2012. 


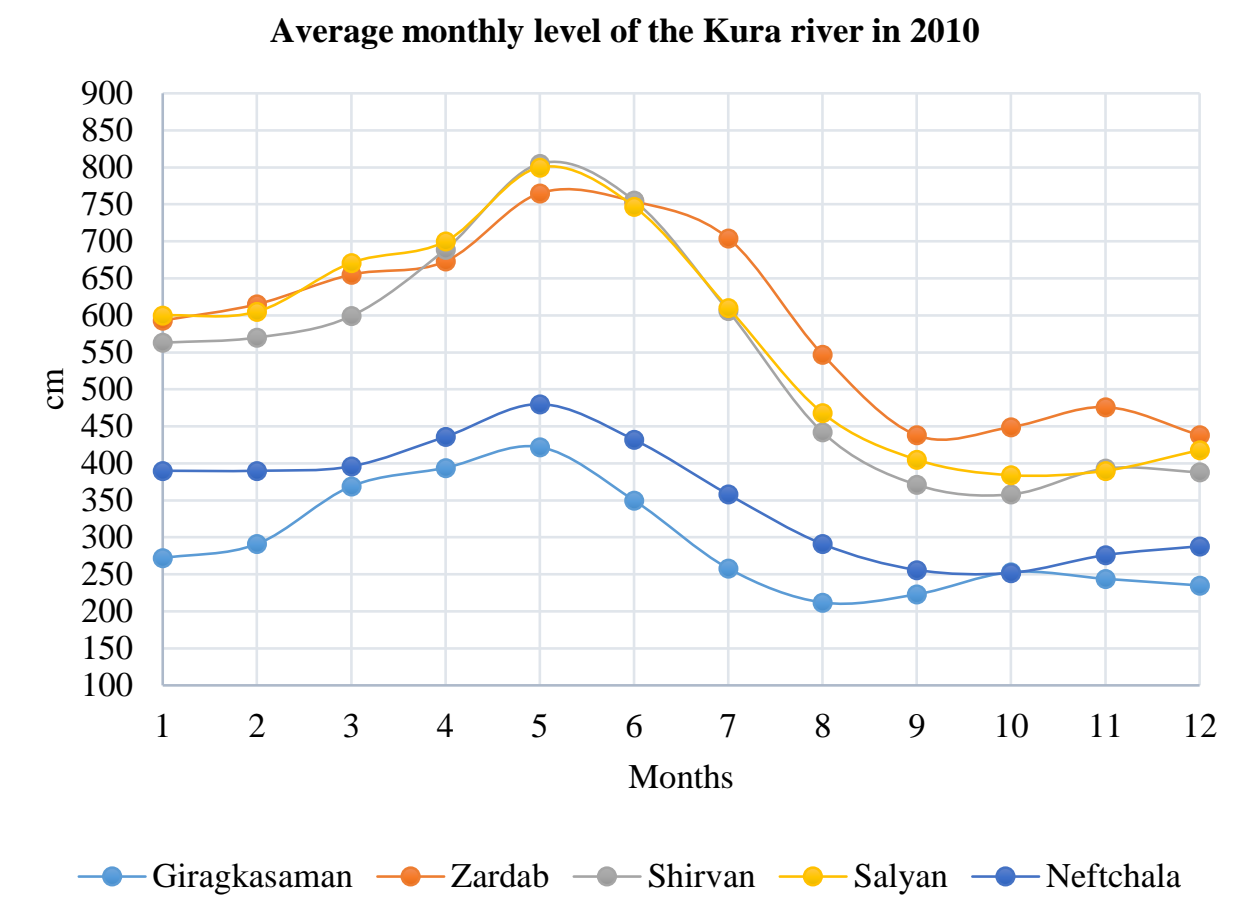

Figure 9. Variation tendency of the average monthly level of the Kura River over different stations in 2010.

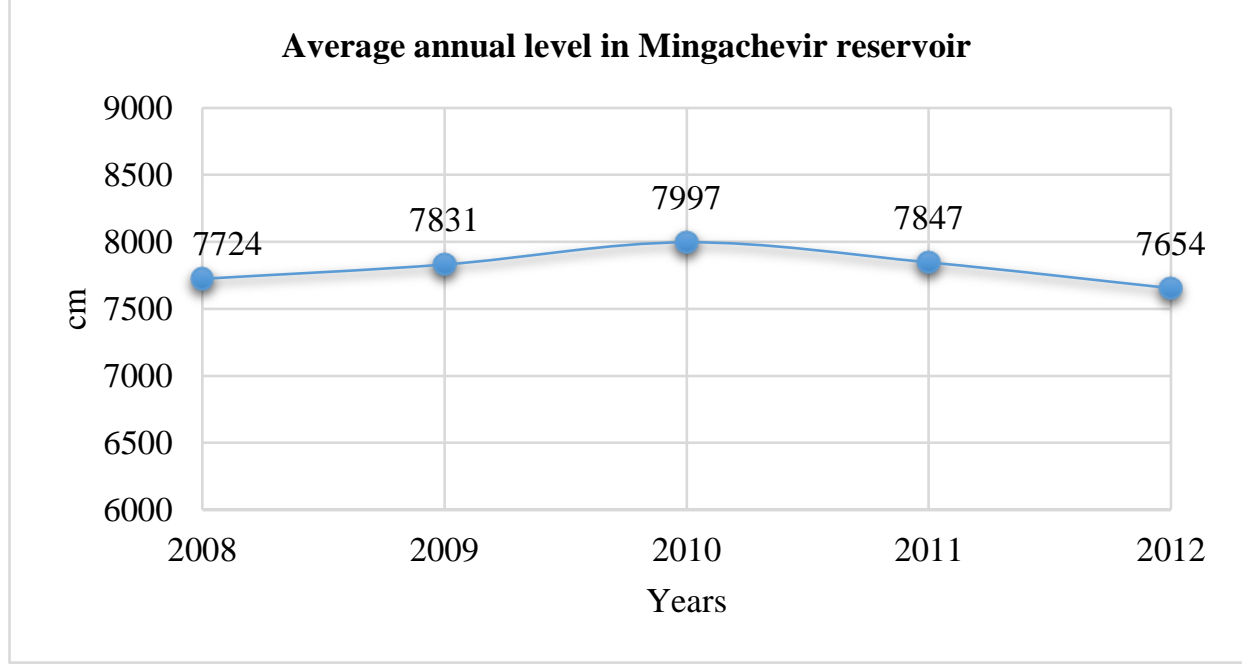

Figure 10. Average annual level in Mingachevir reservoir during 2008-2012.

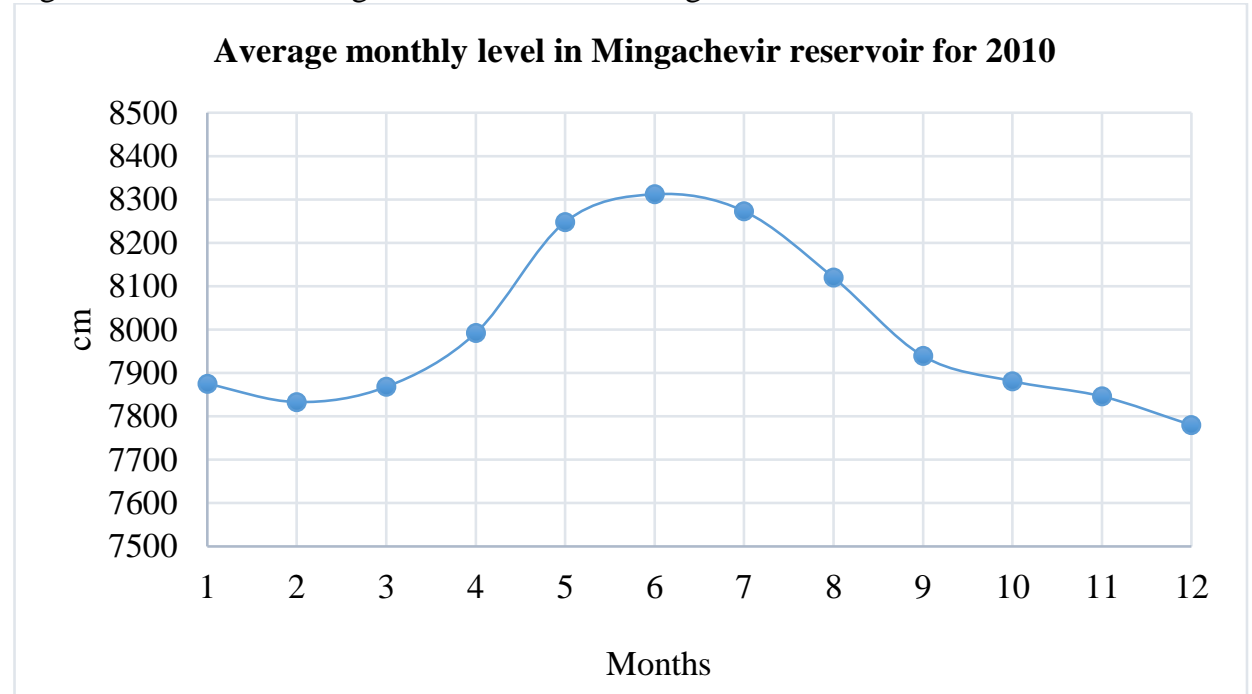

Figure 11. Variation tendency of the average monthly water level in Mingachevir reservoir for 2010. 
Along with the high level of precipitation in April, May and June in 2010 in the country, the increase in water level of the Kura River was observed. The analysis of hydrological observation data shows that the average monthly water level of the Kura River in Zardab, Shirvan and Salyan stations was high in both three months (Fig. 9).

The potential of the Mingachevir water reservoir on the Kura River was utilized maximum for the regulation of water runoff of the Kura River and volume of the water almost reached the maximum level. Utterly the reasons for the flooding were maximum level of the water in Mingachevir water reservoir and excess release of the water. Comparing with other years, the water level in
Mingachevir reservoir from 2008 to 2012 was actually high in 2010. So, the level was $7997 \mathrm{~cm}$ in Mingachevir reservoir in 2010 (Fig. 10). In a viewed case the water level was high mainly in May and June in 2010 in Mingachevir reservoir, so the flooding coincided with the same months. The next graph illustrates that the maximum extent was $8320 \mathrm{~cm}$ in the end of May an in the beginning of June in the reservoir (Fig. 11).

Beside the analysis of meteorological data, the usage of satellite data was necessary for the determining of the flood extent. For that reason internet resources of USGS (URL 1) and Landsat 5 TM multispectral satellite images were used for the objective of the study (Table 1, Fig. 12).

Table 1. Parameters of acquired satellite images

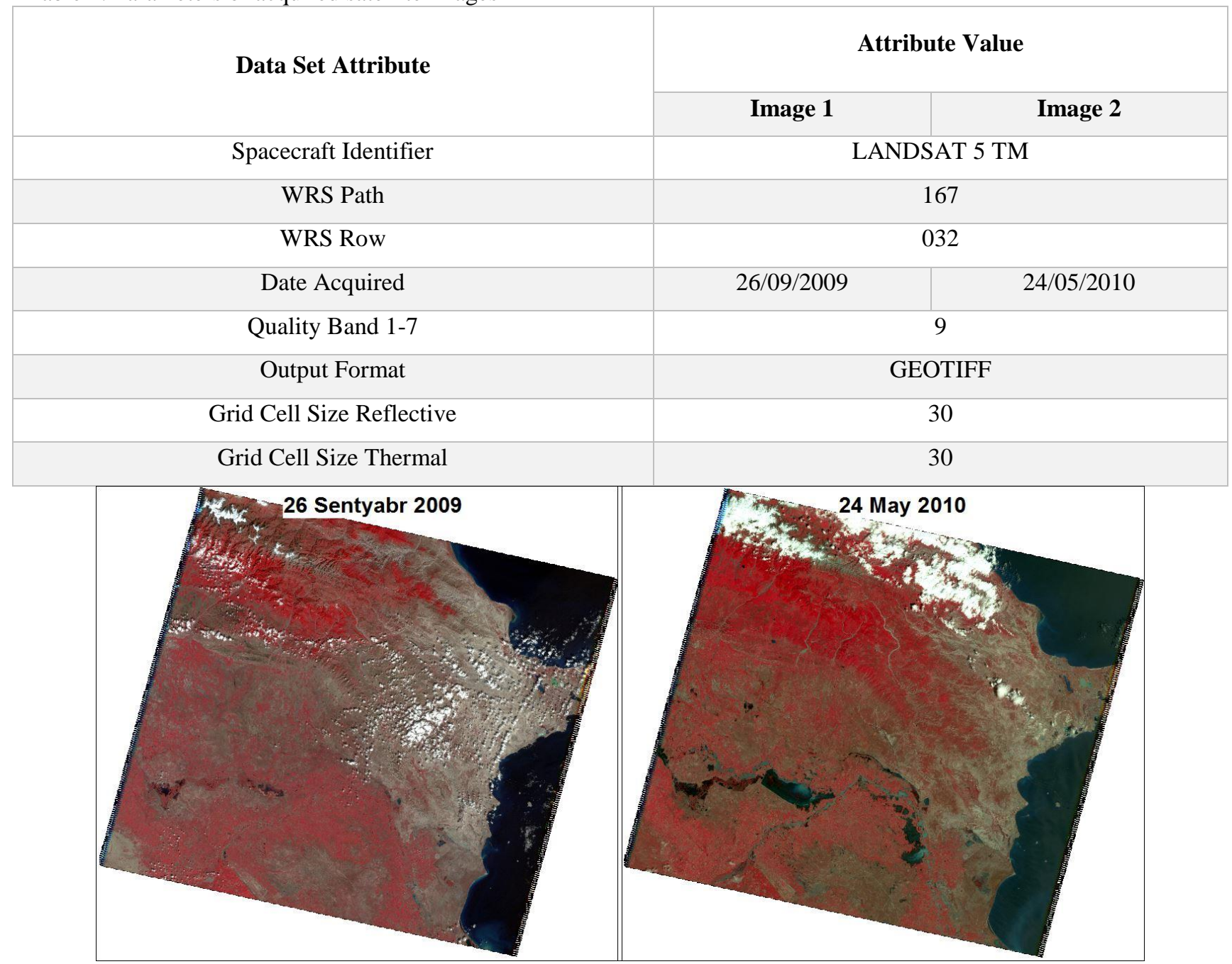

Figure 12. Obtained multispectral images from Landsat 5 TM satellite at different dates.

\section{Conclusion}

Based on acquired satellite images, delineation of inundated areas was conducted by the different tools of ArcGIS software and the extent of flooded areas was revealed (Fig. 13).

The assessment of hydro-meteorological parameters that could cause flooding and trend of the water level with the comparison of perennial norm in the Kura River was conducted, systematic diagram of statistical data was presented, as well as statistical analysis of temperature changes for the period of 2008-2012, precipitation amount and fluctuations of water level in Mingachevir reservoir were conducted.

Final map of the water bodies on the multispectral satellite images for different period was developed through different tools of ArcGIS software. 

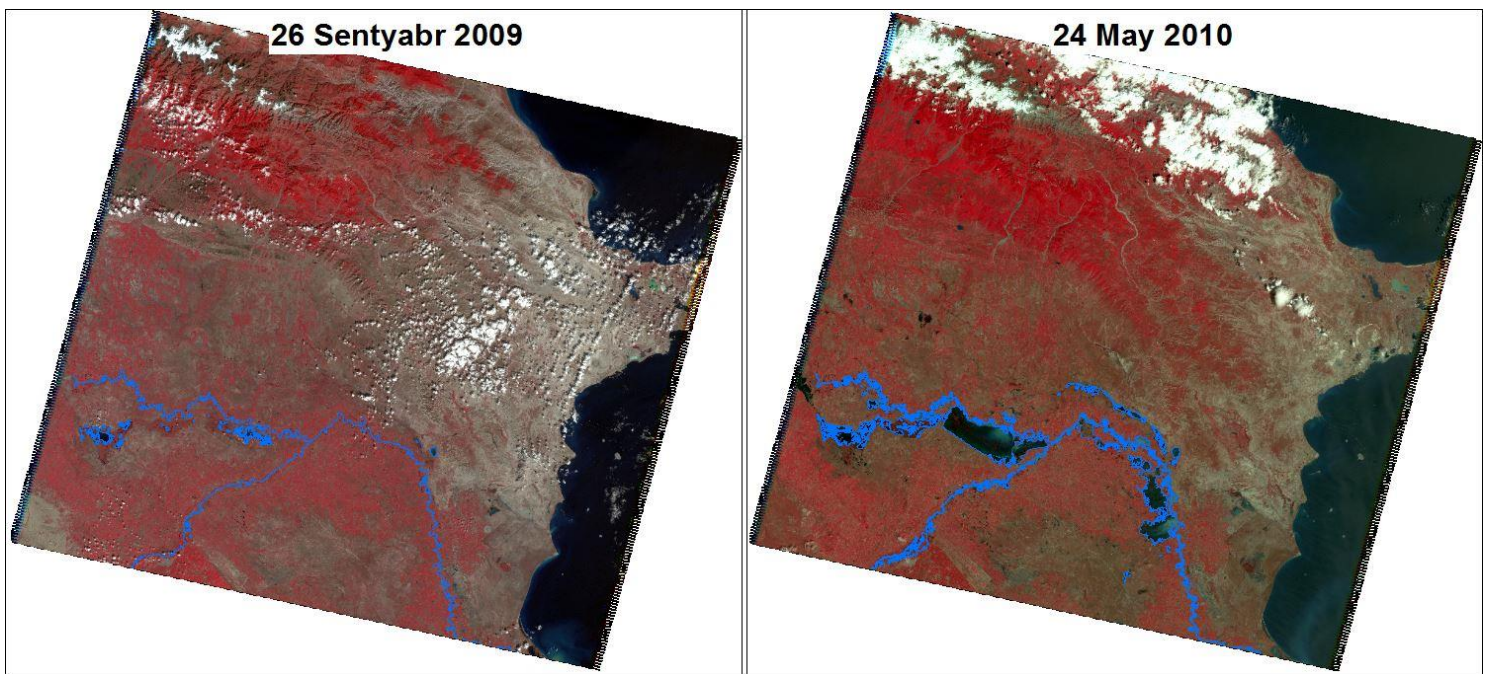

Fig. 13. Results from satellite images.

\section{References}

Abbasov R.K., Mahmudov R.N. (2009). Analysis of non-climatic origins of floods in the downstream part of the Kura River, Azerbaijan. Natural Hazards, Vol. 50(2): 235-248.

Ab. Ghani, A., Sinnakaudan, S., S. Ahmad, MS., Zakaria, N.A., Abdullah, R. \& Abustan, I.(1999). Issues and Practices in Designing a Holistic Flood Risk Mapping System. National Civil Engineering Conference-AWAM 99, Lumut, Perak, Malaysia, 1999.

Aslanov H.Q. (2013). Kürün aşă̆ axarının ekocoğrafi problemlari. Bakı: Çaşığlu, 2013, 234. (En: Aslanov H.G., Eco-geographical problems of the downstream of the Kura River. Baku: Chashioghlu, 2012, 234.

Badalova, A., İsmatova, K., Guliyeva, S. (2019). Influence of Riverbed Change on a Possibility of Flooding During Water Level Rise of the River Kura, International Journal of Environment and Geoinformatics (IJEGEO), Vol. 6 (1), 148-152.

Büyüksalih, İ., Gazioğlu, C. (2019). New Approach in Integrated Basin Modelling: Melen Airborne LIDAR, International Journal of Environment and Geoinformatics (IJEGEO), Vol. 6 (1): 22-32.

Есо-миграция в Азербайджане-Тенденичия, динамика и проблемь, Баку, 2013, 95. (En: Eco-migration in Azerbaijan-Tendency, dynamics and problems. Baku, 2013, 95.)

Ertek, TA., Erginal, AE., Gazioğlu, C., Yücel, ZY. (2003). Tectonically-Induced Drainage Development in Gelibolu Peninsula, MEDCOAST 03.

ESRI (1996). Using the ArcviewGIS Spatial Analyst. Environmental System Research Institute Inc, New York, USA.

ESRI (2001). Using the ArcviewGIS Dialogue Designer (version 1.0). Environmental System Research Institute Inc, New York, USA.

ESRI. (1992). Understanding GIS: The Arc/Info Method. Environmental System Research Institute Inc, New York, USA.

Farhan, M., Moazzam, Ul., Vansarochana, A., Rahman, AU. (2018). Analysis of flood susceptibility and zonation for risk management using frequency ratio model in District Charsadda, Pakistan, International
Journal of Environment and Geoinformatics (IJEGEO), Vol.5 (2), 140-153.

Gazioğlu, C., Alpar, B., Yücel, ZY., Müftüoğlu, AE., Güneysu, C., Ertek, TA., Demir, V., Kaya, H. (2014). Morphologic Features of Kapıdağ Peninsula and its Coasts (NW-Turkey) using by Remote Sensing and DTM, International Journal of Environment and Geoinformatics (IJEGEO), Vol. 1(1): 48-63.

John N. Hatzopoulos. (2002). Geographic Information Systems (GIS) in water management. Proceedings of the 3rd International Forum Integrated Water Management: The key to Sustainable Water Resources.

Махмудов Р.Н. (2001). Прогноз дождевых паводков горных рек Азербайджана. Баку. 203. (En: Mahmudov R.N. (2001). Forecasting of rain floods of mountainous rivers of Azerbaijan. Baku 203.)

Mahmudov R.N. (2014). Azarbaycanda təhlükali hidrometeoroloji hadisalar, Bak1, 130. (En: Mahmudov R.N. (2014). Hazardous hydrometeorolo gical events in Azerbaijan, Baku, 2014, 130.)

Mahmudov R.N. (2015). Azarbaycanda hidrometeoroloji şəraitin təhlli. Bak1: Ziya, 312. (Mahmudov R.N. (2015). Analysis of the hydrometeorological condition in Azerbaijan. Baku: Ziya, 312.)

Махмудов Р.Н. (2016). Региональные климатические изменения и речной сток в Азербайджане. Метеорология и гидрология, Москва, № 6. (En: Mahmudov R.N. (2016). Regional climate changes and river discharge in Azerbaijan. Meteorology and Hydrology, Moscow, № 6.)

Rashidin, MS., Javed, S., Liu, DB., Tafsirojjaman, T. (2019). An Empirical Investigation on HydroMorphological Process of Surma River: Substantiation from North-East Zone of Bangladesh, International Journal of Environment and Geoinformatics (IJEGEO), Vol. 6 (1), 83-114.

Sinnakaudan S.K., Ab. Ghani, A., Mohd. Sanusi, S. Ahmad, Zakaria, A. (2003). Flood risk mapping for Pari River incorporating sediment transport. Environmental Modelling \& Software, Vol. 18: 119. 130.

URL 1. http://earthexplorer.usgs.gov

URL 2. http://www.fhn.gov.az/index.php?aze/pages/33. 